\title{
Keluarga Sebagai Pusat Misi Masa Kini
}

\author{
Candra Gunawan Marisi, ${ }^{1} *$ Didimus Sutanto, ${ }^{2}$ Ardianto Lahagu ${ }^{3}$ \\ Prodi PK-AUD, Sekolah Tinggi Teologi Real Batam \\ Prodi PKAUD, STAKPN Sentani \\ Prodi PAK, Sekolah Tinggi Teologi Real Batam \\ candragun@sttrealbatam.ac.id
}

\begin{abstract}
Bible study has always placed the mission as the pulse of the preaching and mandate must be done by from time to time. The family has occupied the central role of mission in the Bible. The current mission perspective requires a review as the role of the family fades in the midst of the oasis of carrying out the great commission's mission today. Mission has become something strange for believers do. The purpose of this study is to find the relationship between family and the implementation of the great mission of God almighty. How far all families in practicing the great mission of God almightyThe extent This study uses a qualitative method by analyzing data and related information. This research also uses descriptive method investigating the literature related to the topic, including interpreting the Scriptures related to the topic to get data about the importance of making the family as the center of today's mission. The data found is also associated with phenomena occur as a result of a co-pandemic 19, the church must start worshiping at home. Evangelism missions must still be carried out despite of many challenges and obstacles. The family must be the center of mission and start to the mission. Even the Church must restart what was done by the Apostle Paul and the early church worshiping in the household to continue the mission of Evangelism and strengthen the faith of Christian families and raise the soul of mission to family members.
\end{abstract}

Keywords: Family, Mission, Present / New Normal.

\begin{abstract}
Abstrak
Kajian Alkitab selalu menempatkan misi sebagai denyut nadi pemberitaan dan mandat yang terus dikerjakan oleh tokoh-tokoh Alkitab dari masa ke masa. Keluarga telah menempati peran sentral misi dalam Alkitab. Perspektif misi masa kini memerlukan pengkajian ulang seiring meredupnya peran keluarga di tengah oasis pelaksanaan misi amanat agung dewasa ini. Misi telah menjadi sesuatu yang asing dikerjakan oleh sebagian orang percaya. Tujuan penelitian ini adalah untuk
\end{abstract}


menemukan hubungan antara keluarga dengan pelaksanaan misi amanat agung. Sejauh mana peran keluarga dalam melaksanakan misi amanat agung. Penelitian ini menggunakan metode kualitatif dengan menganalisa data dan informasi terkait. Penelitian ini juga menggunakan metode deskriptif yakni menyelidiki literatur yang berkaitan dengan topik, termasuk menafsirkan ayat firman Tuhan yang berkaitan dengan topik untuk mendapatkan suatu data tentang pentingnya menjadikan keluarga sebagai pusat misi masa kini. Data yang ditemukan juga dikaitkan dengan fenomena yang terjadi akibat dari pandemi covid-19, di mana gereja harus hadir dan mulai ibadah dalam rumah tangga. Misi Penginjilan harus tetap dilaksanakan walaupun banyak tantangan dan rintangan. Keluarga harus menjadi pusat misi dan memulai untuk bermisi. Bahkan Gereja harus memulai kembali apa yang dilakukan oleh Rasul Paulus dan gereja mula-mula, yakni ibadah dalam rumah tangga untuk melanjutkan misi Penginjilan dan memperkuat iman keluarga-keluarga Kristen dan membangkitkan jiwa misi kepada angota keluarga.

Kata Kunci: Keluarga, Misi, Masa Kini / New Normal

\section{PENDAHULUAN}

Amanat Agung merupakan mandat misi Kristen, yang tertulis dalam Injil Matius 28: 18-20. Dalam ayat ini, Yesus yang sudah bangkit dari kematian berdiri di puncak gunung di Galilea untuk memberikan amanat-Nya yang terakhir kepada para murid-Nya. Verkuyl menyebut bahwa Amanat Agung terdiri dari tiga bagian penting, yaitu: pemberian otoritas dari Yesus, mandat Yesus yang berkesinambungan, dan pemberian sebuah janji penyertaan oleh Yesus. ${ }^{1}$ Amanat Agung bukan hanya sekedar agung tetapi amanat yang paling agung disepanjang sejarah. ${ }^{2}$ Dikatakan agung bila disadari betul siapa Pribadi pemberi amanat ini dan juga mengingat betapa besarnya amanat ini. ${ }^{3}$ Misi Amanat Agung adalah tugas panggilan kekristenan setiap orang percaya. Tugas ini harus dianggap bukan sebagai tugas eksklusif orang tertentu semata. Setiap orang percaya harus menjadi saksi, garam dan terang dunia sehingga dapat membawa orang lain menjadi percaya kepada Yesus Kristus sebagai Tuhan dan Juruselamat mereka. Dwirahardjo dalam penelitian tentang misi Amanat Agung, menegaskan tentang pentingnya gereja untuk mengobarkan kembali api misi yang seakan redup di masa

\footnotetext{
1 Johannes Verkuyl et al., "Johannes Verkuyl Dalam John R. W. Stott, Johannes Verkuyl, Dkk., Misi Menurut Perspektif Alkitab, Dasar Dan Prinsip Penginjilan Sedunia (Jakarta: Yayasan Komunikasi Bina Bangsa, 2007), Hal $73-75^{\prime \prime}$ (2007): 2007.

2 "Stephen Tong.Pdf," n.d.

3 "Jim Petersen Dan Mike Shamy, Menjadi Garam Dan Terang Bagi Kalangan Terdekat, Bandung: Pioner Jaya, 2007 Hal 7" (2007): 2007.
} 
kini. ${ }^{4}$ Melaksanakan misi Amanat Agung di masa sekarang harus memperhatikan konteks dunia sekarang, bukan hanya berpatokan pada masa-masa lalu hingga ke zaman para rasul juga disesuaikan dengan kondisi masa kini. ${ }^{5}$

Masa kini atau dikenal sebagai masa Postmodern sekarang ini, memiliki tantangan tersendiri dalam melaksanakan misi Amanat Agung. Di mana dengan kemajuan teknologi telah membentuk manusia menjadi individualis. Hidup di era media sosial tetapi tidak dibarengi dengan kepekaan sosial. Ketergantungan akan teknologi telah menjangkiti manusia masa kini. Kemudahan mendapat informasi dan berbagi informasi dengan cepat tanpa mempertimbangkan kebenarannya terlebih dahulu, sehingga menjadi ajang menebar berita bohong (hoax). Saling mencaci dan mencari sensasi sudah menjadi tontonan sehari-hari. Akses internet dimanfaatkan untuk kemajuan tetapi sekaligus untuk kehancuran generasi. Kontenkonten negatif merebak di dunia maya, di mana anak-anak dengan mudah mendapatkannya. Hal ini tanpa disadari telah menjadikan generasi ini dimuridkan oleh teknologi. Budaya postmodern ini memiliki unsur positif maupun negatif baik dalam bidang teknologi maupun informasi, sehingga gereja atau keluarga harus selalu ditempatkan pada posisi netral dalam menjalankan misi amanat agung. ${ }^{6}$

Peran orang tua sebagai keluarga yang merupakan tameng terdepan guna membentengi anak-anak mereka dari pengaruh negatif teknologi tidak berfungsi. Orang tua abai mendampingi anak-anak mereka dan mendidiknya sesuai kebenaran firman Tuhan. Bahkan orang tua gagal menjadi figur yang dapat diteladani oleh anak-anak mereka. Banyak anak-anak yang mengalami fatherless (kehilangan kasih bapa). Dengan kata lain, keluarga gagal menjalankan misinya sebagai garam dan terang dunia. Perlu adanya kesadaran kolektif dari setiap orang percaya bahwa keluarga merupakan pusat misi. Hubungan menjadi penting dalam keluarga seperti yang dijelaskan oleh Fredy Simanjuntak, pola hubungan merupakan inti dari seluruh pelayanan dan kehadiran Yesus selama melakukan seluruh pekerjaan-Nya di Bumi. Yesus dalam kesehariannya menempatkan diri-Nya di tengah-tengah orang banyak, mulai dari keluarga sampai kepada anak-anak. ${ }^{7}$ Dari keluarga, anakanak belajar mengenal Tuhan dan kebenaran akan firman-Nya. Waktu terbanyak

\footnotetext{
${ }^{4}$ Susanto Dwiraharjo, "Kajian Eksegetikal Amanat Agung Menurut Matius 28 : 18-20," Jurnal Teologi Gracia Deo 1, no. 2 (2019): 56-73.

${ }^{5}$ Handreas Hartono, "Mengaktualisasikan Amanat Agung Matius 28 : 19-20 Dalam Konteks Era Digital," KURIOS (Jurnal Teologi dan Pendidikan Agama Kristen) 4, no. 2 (2018): 157-166.

${ }^{6}$ Fransiskus Irwan Widjaja, Fredy Simanjuntak, and Noh Ibrahim Boiliu, "Repositioning Mission in Postmodern Culture," in Proceedings of the 1st International Conference on Education, Society, Economy, Humanity and Environment (ICESHE 2019) (Paris, France: Atlantis Press, 2020), https://www.atlantispress.com/article/125936174.

${ }^{7}$ Fredy Simanjuntak, "Problematika Disorganisasi Dan Disharmonisasi Keluarga," in Keluarga Yang Misioner, 2018, 81-91.
} 
pendidikan anak bukanlah di sekolah atau pun di gereja, tetapi justru di rumah, di dalam keluarga.

Pengertian dan paradigma yang keliru tentang misi adalah misi seakan menjadi satu kata yang asing atau menakutkan dan harus dijauhi. Bahkan, mungkin masih ada yang menganggap misi adalah kategori pelayanan yang dikerjakan orang-orang Barat. Sementara itu yang lain berpikir bahwa misi itu, pekerjaan yang hanya bisa dikerjakan oleh penginjil, karena keluarga Kristen tidak merasa terpanggil untuk terlibat dalam pelayanan misi. Dengan demikian peran keluarga hanya dipandang sebagai salah satu komunitas dari segi fungsionalisme belaka. Lebih banyak lagi yang beranggapan bahwa terlibat dalam pekerjaan misi adalah bagian dari orang-orang tertentu. Bahkan ada keluarga-keluarga kristen yang sama sekali tidak menaruh perhatian terhadap misi. ${ }^{8}$ Pada akhirnya keberadaan keluarga kristen menjadi tidak dapat berfungsi optimal di tengah-tengah dunia, di mana Allah menempatkan keluarga sebagai alat untuk menerangi dan menggarami dunia. ${ }^{9}$ Bukankah misi adalah tugas dan tanggung jawab keluarga Kristen yang sudah percaya?

\section{METODE}

Penelitian ini menggunakan metode kualitatif $^{10}$, penulis mengumpulkan data-data dari berbagai sumber, yang kemudian di analisa dan dikembangkan sebagai bagian analisa data. Penelitian ini juga merupakan penelitian deskriptif ${ }^{11}$ yakni menyelidiki literatur yang berkaitan dengan topik, termasuk menafsirkan ayat firman Tuhan yang berkaitan dengan topik untuk mendapatkan suatu data tetang pentingnya menjadikan keluarga sebagai pusat misi masa kini. Dalam Penelitian ini setelah data yang ditemukan juga dikaitkan dengan fenomena yang terjadi akibat dari pandemi covid-19, gereja harus hadir dan mulai ibadah dalam rumah tangga.

\section{HASIL DAN PEMBAHASAN}

\section{Perspektif Misi Masa Kini}

Sebelum membahas tentang perspektif misi masa kini, akan dijelaskan terlebih dahulu pengertian tentang misi. "Istilah Misi (Mission) berasal dari kata Latin "missio" yang diangkat dari kata dasar "mittere," yang berkaitan dengan kata:

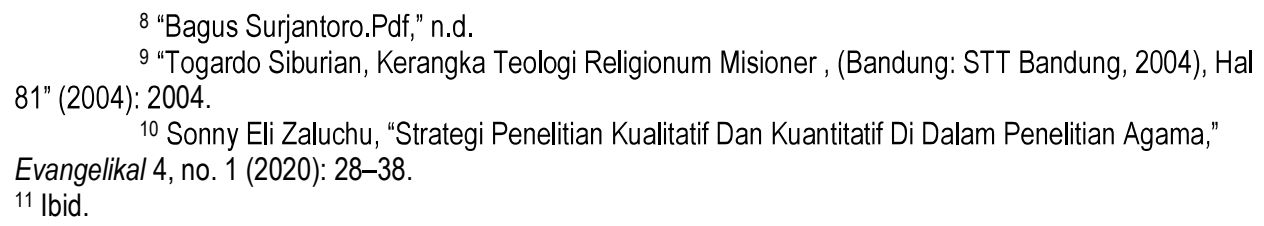


"missum", yang artinya "to send" (mengirim/ mengutus)." "Dalam tulisan ini, misi berarti mengutus seseorang untuk mengabarkan kabar keselamatan tentang Yesus kepada semua makhluk. Yang dimaksud semua makhluk adalah orang yang belum percaya kepada Tuhan Yesus, baik itu orang yang paling dekat yaitu keluarga maupun orang lain.

Dalam mandat penciptaan, ketika Allah menyatukan manusia (Adam dan Hawa) adalah untuk beranak cucu dan memenuhi bumi. Kata beranak cucu yang dimaksud bukan hanya sekedar perintah berkembang biak, tetapi adalah untuk memenuhi bumi dengan keturunan illahi, memenuhi bumi dengan gambar Allah. Tetapi manusia telah jatuh dalam dosa dan kehilangan kemuliaan Allah. Manusia menjadi gambar Allah yang rusak. Manusia telah gagal melaksanakan perintah Allah, tetapi Allah tidak pernah gagal. Allah tetap mengasihi manusia dan memiliki rencana besar untuk menyelamatkan manusia. Meador menyebut ada empat tema besar dalam Alkitab, yaitu: penciptaan, kejatuhan, penebusan dan penyempurnaan. ${ }^{13}$

Setelah kejatuhan manusia dalam dosa, Allah memberikan janji keselamatan yang paling awal dalam Kej. 3:15 (proto evangelium). Dalam perkembangannya semua nabi memanggil orang berdosa untuk bertobat kepada Allah. ${ }^{14}$ Misi Allah adalah untuk mengembalikan manusia kembali kepada kultur penciptaan, yaitu menjadi gambar Allah yang utuh. ${ }^{15}$ Hal ini telah dilaksanakan dengan sempurna oleh Yesus Kristus tatkala berinkarnasi menjadi manusia. Oleh karenanya, setiap manusia harus menjadi seperti Kristus. Menjadi seperti Kristus adalah meneladani Kristus, hidup seperti Kristus dalam menjalani kehidupan di dunia ini.

Dalam Kej. 3:15, di mana sering disebut sebagai proto evangelium, Allah telah menubuatkan akan rencana besar-Nya menyelamatkan manusia. Kelak nubuatan ini digenapi dalam pribadi Yesus Kristus, tujuan akhir segala sesuatu adalah Allah bukan manusia. Oleh karenanya, sasaran akhir dari gereja adalah keselamatan jiwa-jiwa. Ibadah adalah kehidupan yang penuh pengabdian dan penyembahan kepada Kristus. Dengan kata lain, hal yang paling penting dalam kehidupan orang percaya adalah sentralitas Allah dalam kehidupannya. Jika demikian, di manakah posisi misi? Penyelamatan adalah sasaran dan bahan bakar misi. Dengan kata lain tugas misi dimulai dan diakhiri dengan penyelamatan. ${ }^{16} \mathrm{Kej}$.

12 "Yakob Tomatala, Teologi Misi.Pdf," n.d.

13 "Gery T Meador.Pdf," n.d.

14 "Yakob Tomatala.Pdf," n.d.

${ }^{15}$ Fransiskus Irwan Widjaja, Misiologi Antara Teori, Fakta Dan Pengalaman, 1st ed. (Batam: Andi Offset Yogyakarta, 2018).

16 "John Piper, Jadikan Segala Bangsa Bersuka Cita (Bandung: Lembaga Literatur Baptis, 1993), Hal 7 - 8" (1993): 1993. 
3:15, Gal. 3:8 menyatakan bahwa Allah sendiri yang menginjili Abraham. Dengan demikian isi berita penginjilan dalam Perjanjian Lama adalah melalui Abraham, Allah akan memberkati segala bangsa. Dalam Kejadian pasal 12 Allah memilih Abraham untuk meninggalkan dunia orang kafir dan akan menjadi berkat bagi semua orang. "Kisah pemilihan Abraham dan keturunannya merupakan persiapan bagi pemilihan Israel yang berwujud Keluaran dari Mesir." ${ }^{17}$ Dalam Keluaran 19: 5-6, dikatakan "...kamu akan menjadi harta kesayangan-Ku sendiri dari antara segala bangsa, sebab Akulah yang empunya seluruh bumi. Kamu akan menjadi bagi-Ku kerajaan imam dan bangsa yang kudus..." Ayat ini menyatakan bahwa Israel di antara segala bangsa merupakan suatu gambaran pemerintahan Allah dan suatu gambaran pelayanan selaku imam.

Dalam Perjanjian Baru, inti-pusat berita Injil adalah maklumat Yesus tentang Kerajaan sorga yang sudah dekat (Mat. 4: 17). Oleh sebab itu, para pendengar Injil harus bertobat. Tuhan Yesus sebelum naik ke sorga, Ia memberi perintah kepada murid- murid-Nya untuk memberitakan Injil. Dikatakan dalam Matius 28 : 16-20: “...Kepada-Ku telah diberikan segala kuasa di sorga dan di bumi. Karena itu pergilah, jadikanlah semua bangsa murid-Ku dan baptislah mereka dalam nama Bapa dan Anak dan Roh Kudus, dan ajarlah mereka melakukan segala sesuatu yang telah Kuperintahkan kepadamu..." Di mana dalam ayat ini mengandung tiga garis besar dalam Amanat Agung Tuhan Yesus, yaitu: 1). Otoritas pemberitaan injil adalah dari Allah sendiri; 2). Pemberitaan injil adalah aktifitas menjadikan semua orang (bangsa) menjadi murid Kristus bukan murid sendiri. Sehingga pusat misi adalah pemuridan Kristus; 3). Penyertaan Allah dalam pemberitaan injil sebagai dorongan motivasional orang percaya melaksanakan amanat agung. ${ }^{18}$ Demikian juga dikatakan dalam Markus $16: 15$, “...Pergilah ke seluruh dunia, beritakanlah Injil kepada segala makhluk..." Hal ini menunjukkan bahwa Injil harus diberitakan kepada semua orang, baik itu mulai dari anak-anak sampai orang tua dari berbagai ras dan golongan.

Dalam Kisah Para Rasul 1:8 dikatakan: "Tetapi kamu akan menerima kuasa, kalau Roh Kudus turun ke atas kamu, dan kamu akan menjadi saksi-Ku di Yerusalem dan di seluruh Yudea dan Samaria dan sampai ke ujung bumi." Hal ini menunjukkan bahwa setiap orang diberi kuasa untuk menjadi saksi Tuhan baik itu di keluarga, tempat bekerja, sekolah, masyarakat dan di mana saja.

Dalam konteks masa kini pengertian misi mulai mengalami kemunduran makna. Misi dipahami sebagai mandat yang hanya dapat dilaksanakan oleh orang tertentu, dalam hal ini hamba Tuhan (misionaris). Misi hanya dilakukan oleh

\footnotetext{
17 "Arie De Kuiper.Pdf," n.d.

${ }^{18}$ Dwiraharjo, "Kajian Eksegetikal Amanat Agung Menurut Matius 28 : 18-20."
} 
lembaga misi. Misi bukan menjadi tanggung jawab semua orang percaya termasuk keluarga kristen. Akibatnya misi menjadi suatu hal yang asing bagi keluarga kristen. Lebih ironis lagi, di mana gereja sebagai tempat yang harusnya mengajarkan tanggung jawab misi kepada setiap orang percaya justru terbuai dengan kompetisi semu pada persaingan kemegahan pelayanan gerejawi pada tataran fisikal semata. Sebagian besar penggunaan dana gereja bukan untuk melaksanakan misi penjangkauan ini.

Sementara tantangan misi di masa kini ada di depan mata. Dunia masa kini berada pada era postmodern, masa di mana ciri utamanya orang menghargai spiritualitas tanpa harus religius. Menghargai kepelbagaian, dipengaruhi oleh teori relativisme. Tidak ada kebenaran absolut, karena menurutnya segala sesuatu ada alasan dibaliknya sehingga menempatkan kebenaran bersifat subyektif. Munculnya era teknologi informasi cybernet yang begitu cepat. ${ }^{19}$ Apalagi di tengah pandemi Covid-19, dunia cyber telah menjelma menjadi kebutuhan yang tak terganti. Bekerja dari rumah, belajar dari rumah, bahkan beribadah dari rumah telah menjadi tradisi baru belakangan ini. Hal ini memunculkan gereja berada pada ruang virtual, Cyber-Church. Ini merupakan suatu tantangan nyata di depan mata pada era masa kini. Hal ini menjadi suatu kesempatan tetapi sekaligus ancaman perspektif misi masa kini.

\section{Pengertian Keluarga}

Keluarga merupakan lembaga yang Tuhan ciptakan. Konsep keluarga dipandang sebagai hal yang hakiki bagi perkembangan bangsa. Dalam memikirkan manusia, maka segi individunya harus diimbangi dengan segi solidaritasnya. Hal ini bukan saja terlihat dalam keluarga, tetapi juga dalam kehidupan bangsa Israel. Fakta memperlihatkan adanya rasa solidaritas yang kuat di antara umat Israel, yang didasarkan atas anggapan bahwa bangsa itu merupakan keluarga yang besar. ${ }^{20}$ Sedangkan menurut Sigmund Freud, pada dasarnya keluarga itu terbentuk karena adanya perkawinan pria dan wanita. Bahwa menurutnya keluarga merupakan manifestasi dari pada dorongan seksual sehingga landasan keluarga itu adalah kehidupan seksual suami isteri. Maka dapat dipahami bahwa Pengertian Keluarga adalah sekumpulan orang (rumah tangga) yang memiliki hubungan darah atau perkawinan atau menyediakan terselenggaranya fungsi-fungsi instrumental mendasar dan fungsi-fungsi ekspresif keluarga bagi para anggotanya yang berada dalam suatu jaringan.

19 Tantangai Dan et al., "Ke-L8, Dan" (n.d.)

20 "Donald Guthrie, Teologi Perjanjian Baru 1, Allah, Manusia, Kristus , (Jakarta: BPK Gunung Mulia, 1992), Hal 105" (1992): 1992. 
Pengertian keluarga menurut KBBI tentu saja berbeda dengan pengertian keluarga menurut Kristen. Keluarga dalam perspektif Kristen selalu identik dilambangkan dengan gereja sebagai tubuh Kristus. Untuk lebih jelasnya, berikut adalah pengertian keluarga dalam perspektif Kristen: (1) Sebuah lembaga yang keberadaannya menunjukkan penghayatan terhadap Yesus Kristus. Jadi, keluarga Kristen bukan hanya sebatas simbol atau unsur saja, melainkan sebuah kesatuan dan keikutsertaan pada ajaran-ajaran maupun ibadah-ibadah gerejawi; (2) Tempat untuk bertumbuh, berkembang, dan berbagi baik dalam iman, kasih, dan harapan. Iman akan Yesus Kristus bisa diasah dalam sebuah keluarga. Peran orang tua sangat dibutuhkan di sini. Tanpa adanya pengawasan orang tua, iman tersebut tidak akan terwujud; (3) Sebagai tempat untuk melakukan aktivitas rohani. Aktivitas yang dimaksudkan ialah berbagi dan mengasihi sesama anggota keluarga. Setiap anggota keluarga boleh melakukan aktivitas rohani masing-masing. Baik di dalam keluarga maupun di dalam perkumpulan gereja; (4) Keluarga adalah tempat untuk mentransfer nilai-nilai kehidupan. Melalui keluarga akan diajarkan tentang moral kehidupan sehingga dapat berjalan lurus tanpa adanya sikap yang menyeleweng; (5) Sebagai tempat untuk memperhatikan dan mentransfer energi untuk lebih dekat dengan ajaran Yesus Kristus. Poin ini berkaitan dengan tujuan hidup orang Kristen.

\section{Hubungan Keluarga dan Misi}

Dalam menjalankan rencana penyelamatan-Nya, Allah selalu memakai keluarga. Keluarga sebagai sumber gerakan misi Allah. Allah memulai misi-Nya bagi dunia melalui keluarga. Allah tidak memulai misi-Nya dari gereja atau persekutuan-persekutuan orang percaya, tetapi dari komunitas manusia yang dibentuk-Nya pertama kali yaitu keluarga. Keluarga merupakan tempat pertama untuk mengajarkan dan mentaati firman Tuhan. Perintah, hukum-hukum serta ketetapan-ketetapan Allah yang diberikan pertama dalam keluarga, baik dalam masa penciptaan, zaman Nuh, zaman Abraham, dan seterusnya. Allah memakai keluarga Adam dan Hawa untuk mengajarkan Firman-Nya kepada keturunannya. Walaupun tidak semua keturunannya taat untuk mengikuti dan melakukan perintah Tuhan. Tuhan memakai keluarga Nuh untuk menyatakan kedaulatan-Nya dan melaksanakan misi penyelamatan-Nya kepada manusia (Kejadian 7-9). Manusia menolak karya penyelamatan-Nya dengan menolak bahtera Nuh, sehingga mereka binasa dalam penghukuman. Allah tidak menyerah dan memakai keluarga Abraham, bahkan di zaman Musa, untuk menyelamatkan bangsa Israel dari perbudakan di Mesir, Allah memakai keluarga Musa, yaitu ibu dan kakaknya dengan iman melarung bayi Musa di sungai Nil yang kemudian ditemukan dan diasuh oleh Putri Firaun. Hal ini tidak mungkin terjadi jika ibu Musa tidak beriman terhadap karya penyelamatan Allah kepada umat-Nya (Ibr. 11:23). Dalam misi 
penyelamatan-Nya, Allah selalu memakai keluarga. Memasuki era Perjanjian Baru, fungsi keluarga sebagai tempat bertolaknya misi Allah semakin jelas dengan memakai keluarga imam Zakaria dan Elisabet untuk menghadirkan Yohanes Pembaptis sebagai perintis kedatangan Sang Juru Selamat. Bahkan puncak karya penyelamatan-Nya yang digenapi dalam Yesus Kristus pun, Allah memakai keluarga Yusuf dan Maria. Betapa pentingnya keluarga di mata Tuhan. Hingga pada zaman para rasul, gereja mula-mula dimulai dari keluarga-keluarga. Pada surat-surat penggembalaannya banyak dijumpai di mana penginjilan rasul Paulus selalu menggunakan keluarga sebagai pusat pola misinya. Keluarga bukan hanya komunitas pertama bagi manusia tetapi lebih lagi menjadi sumber gerakan misi Allah bagi dunia.

\section{Pentingnya Keluarga Kristen}

Keluarga adalah anugerah Allah yang tidak ternilai harganya. Keluarga Kristen adalah tempat pendidikan yang pertama menjalankan misi Allah kepada keluarga. Keluarga Kristenlah yang memegang peranan yang terpenting melaksanakan misi Allah. Keluarga adalah sebagai satu kesatuan pokok bagi gereja dan seluruh masyarakat. Apabila keluarga kuat dan sehat, maka gereja dan masyarakat umum pun juga akan kuat. Keluarga adalah suatu persekutuan yang terdiri dari orang-orang yang saling terikat oleh ikatan darah dan perhubungan sosial yang paling kuat. Keluarga Kristen yang telah dikuasai oleh Tuhan Yesus, pasti keluarga itu akan menjadi taat dan kuat di dalam Tuhan dan mereka akan mengembangkan dan mematangkan pribadi-pribadi Kristen yang luhur. Keluarga Kristen merupakan suatu persekutuan antara anak-anak dengan orang tuanya, yang sanggup menciptakan suasana kristen sejati di dalam lingkungan mereka sendiri. Di mana keluarga kristen dapat berfungsi sebagai: 1). Perwakilan Tuhan dalam mengelola alam semesta; 2). Sarana pendidikan yang pertama dan terutama; 3). Tempat untuk menciptakan suasana sorga; 4). Dasar iman sumber keselamatan.

\section{Keluarga Kristen Sebagai Pusat Misi Allah}

Keluarga Kristen memegang peranan yang sangat penting dalam mengajarkan iman kepada anak-anaknya. Alkitab mengisahkan bahwa adanya keluarga-keluarga yang dipakai Allah sebagai jalan dan saluran keselamatan yang dirancangkan Allah bagi umat manusia. Misi dapat dimulai dari keluarga, sebab dalam keluarga tempat pertama seorang anak mendapatkan didikan. Kepribadian dan karakter seseorang tidak dapat dilepaskan dari pendidikan keluarga yang diterima. Keluarga adalah tempat yang Tuhan siapkan untuk menabur dan menanamkan nilai-nilai kehidupan (Ulangan 6:6-7). Karena itu Ayah dan Ibu sebagai inti keluarga sangatlah berperan dalam menanamkan nilai-nilai kepada 
anak-anak mereka. Anak harus dididik dan didorong untuk menerapkan semua nilai luhur sebagaimana diajarkan firman Tuhan, dan dijauhkan dari segala hal yang dilarang. Hal yang penting adalah agar orang tua memiliki kerohanian yang berkualitas dan terampil mendidik anak dalam Tuhan, dibutuhkan anugerah Allah, kemauan dan disiplin diri untuk terus meningkatkan pertumbuhan kerohanian. Selain itu juga diperlukan hasrat dan motivasi yang tinggi untuk memperlengkapi diri guna meningkatkan kemampuan yang berkaitan dengan pendidikan anak.

Mengapa keluarga sebagai pusat dalam bermisi? Beberapa alasan akan diuraikan di bawah ini, yaitu:

\section{Keluarga Dibentuk Atas Inisiatif Allah}

Keluarga merupakan komunitas manusia yang pertama kali dibentuk oleh Allah. Komunitas pertama manusia yang dibentuk Allah adalah keluarga, di mana komunitas ini pun dapat menjadi tempat persekutuan. Kejadian 2 : 18, 21-24 menunjukkan bahwa pembentukkan komunitas pertama kali dilakukan oleh Allah, melalui suatu pernikahan laki-laki dan perempuan, di mana melalui komunitas tersebut terbentuk suatu keluarga yang terdiri dari ayah, ibu dan anak. Jadi keluarga terbentuk bukan atas keinginan atau inisiatif manusia tetapi atas keinginan dan inisiatif Allah. Oleh karena itu di mata Allah keluarga memiliki arti yang sangat penting bagi manusia ciptaan-Nya.

Keluarga Kristen adalah keluarga yang dibentuk atas inisiatif Allah sendiri, oleh karena itu keluarga Kristenlah yang berperan paling penting dalam menjalankan misi Allah. Keluarga Kristen sebagai tempat untuk bernaung dan berlindung bagi seluruh anggota keluarga. Untuk itu, keluarga Kristen harus membuat suasana sorga kepada seluruh anggota keluarga.

\section{Keluarga Tempat Pertama Menerima Injil}

Ulangan 6: 6-9 ${ }^{6}$ Apa yang kuperintahkan kepadamu pada hari ini haruslah engkau perhatikan, ${ }^{7}$ haruslah engkau mengajarkannya berulang-ulang kepada anak-anakmu dan membicarakannya apabila engkau duduk di rumahmu, apabila engkau sedang dalam perjalanan, apabila engkau berbaring dan apabila engkau bangun. ${ }^{8}$ Haruslah juga engkau mengikatkannya sebagai tanda pada tanganmu dan haruslah itu menjadi lambang di dahimu, ${ }^{9}$ dan haruslah engkau menuliskannya pada tiang pintu rumahmu dan pada pintu gerbangmu.

Keluarga merupakan lembaga pertama untuk menerima kebenaran Firman Tuhan, orang tua menabur dan menanamkan nilai-nilai kehidupan yang sesuai 
dengan kebenaran Firman Tuhan mengajarkan lewat kata-kata dan teladan. ${ }^{21}$ Ayah dan Ibu sebagai inti keluarga sangatlah berperan dalam memperkenalkan Kristus bagi anak-anak bahkan bagi semua orang yang tinggal dalam rumah. Anak harus dididik dan didorong untuk menerapkan semua nilai luhur sebagaimana diajarkan firman Tuhan, dan dijauhkan dari segala hal yang dilarang Firman Tuhan. Ayat tujuh menekankan kepada setiap orang tua harus mengajarkan setiap kebenaran Firman Tuhan secara berulang-ulang. Yesus Kristus selalu menjadi topik pembicaraan yang hangat bahkan menjadi suatu tanda atau kebanggaan terhadap anak-anak ditengah banyaknya media informasi yang terbuka di masa kini.

Selain mengajarkan dan menanamkan kebenaran peran yang lebih penting adalah menjadi teladan bagi seisi rumah, sehingga melalui teladan orangtua anakanak mendapatkan gambaran Bapa di Sorga. Selain itu orangtua masa kini juga dapat memetik pelajaran bahwa dimensi perwujudan iman dibarengi dengan dimensi pemahaman iman. Sebab pada saat ini seringkali muncul pemahaman yang berat sebelah, di mana dimensi perwujudan iman yakni bagaimana hidup sebagai orang Kristen dengan baik begitu ditonjolkan namun dimensi pemahaman iman yakni pemahaman tentang Alkitab dan mengasihi Tuhan dengan segenap hati, jiwa, akal budi dan kekuatan kurang mendapat perhatian. ${ }^{22}$ Tidaklah cukup bagi orangtua mengajar dengan kata-kata dan teladan, anak-anak juga harus diajarkan untuk menjadi teladan di mana pun mereka berada. Anak-anak harus menjadikan diri mereka sendiri teladan sebagai pengikut Kristus yang setia kepada anak-anak yang lain di sekolah, lingkungan pertemanan bahkan di lingkungan gereja, anak-anak diajar untuk memberitakan Injil. Memberitakan injil dapat berarti bersaksi, membagi kabar baik, berbagi hidup tentang Kristus kepada setiap orang. ${ }^{23}$ Dengan dimulainya misi dalam keluarga, maka misi ini akan dilanjutkan juga oleh anakanak di lingkungan mereka. Bukan hanya diombang-ambingkan pengajaran yang simpang siur, penerapan Misi yang benar dalam keluarga akan menghasilkan seorang missioner yang militan di dalam keluarga.

\section{Gereja konsentrasi bermisi kepada Keluarga}

Keluarga merupakan salah satu sarana Misi yang dilakukan oleh Rasul Paulus. Rumah tangga juga tempat membina orang-orang percaya di kota-kota di mana Rasul Paulus singgah dalam bermisi. Paulus tinggal di rumah Lidia di Filipi (Kis. 16:15-16), rumah Yason di Tesalonika (Kis. 17:7), rumah Akwila di Korintus

21 Yohanes Krismantyo Susanta, "Tradisi Pendidikan Iman Anak Dalam Perjanjian Lama," BIA': Jurnal Teologi dan Pendidikan Kristen Kontekstual 2, no. 2 (2019): 139-150.

22 Ibid.

${ }^{23}$ Fransiskus Irwan Widjaja, Daniel Ginting, and Sabar Manahan Hutagalung, "Teologi Misi Sebagai Teologi Amanat Agung" 1, no. 1 (2019): 17-24. 
(Kis. 18:1), ruang atas di Troas (Kis. 20:8, 11), rumah Filipus di Kaisarea (Kis. 21:8). Paulus juga melayani jemaat di rumah-rumah tertentu: jemaat di rumah Priskila dan Akwila (Rm. 16:3-5); rumah Aristobulus (Rm. 16:10), rumah Narkisus (Rm. 16:11), Gayus yang memberi tumpangan (Rm. 16:23), jemaat di rumah Nimfa (Kol. 4:15), Paulus pernah tinggal di rumah Karpus di Troas (2 Tim. 4:13). Hasil buah pelayanan dari pemberitaan kabar baik dalam keluarga, juga di tuntaskan di rumah. Hal ini menjelaskan mengapa dalam Perjanjian Baru terdapat banyak baptisan terhadap seisi rumah, misalnya Kornelius (Kis.10:2); Lidia di Filipi (Kis. 16:15) dan kepala penjara (Kis. 16:33), Keluarga Stefanus di Korintus (1Kor. $1: 16$; 16:5). Paulus dalam pelayanannya selalu memulai dari rumah (keluarga). ${ }^{24}$

Gereja seharusnya memusatkan pelayanan misi di rumah-rumah, terlebih dalam kondisi seperti masa kini, di tengah-tengah pandemi Covid-19, di mana gereja diharuskan melakukan ibadah dari rumah. Seolah gereja dipaksa kembali kepada pola Alkitab, yaitu berpusat pada keluarga (di rumah). Dari ibadah rumah, keluarga mengenal misi dan dari rumah juga gerakan misi dimulai. Pada era masa kini, di mana kemajuan teknologi memadai, sangatlah memungkinkan untuk melakukan gerakan misi dari rumah. Dalam hal ini, yang dimaksudkan dalam penelitian ini adalah di mana gereja melakukan pemberitaan Injil di rumah-rumah juga dapat melakukan Ibadah di rumah, bukan hanya sekedar sel grup atau ibadah tengah minggu, melainkan ibadah hari Minggu di dalam rumah tangga. Paulus menggunakan secara khusus rumah tangga untuk mengorganisasi gerakan Kristen mula-mula. ${ }^{25}$ Berkaca dari apa yang dilakukan Paulus dan jemaat mula-mula di dalam Kisah Para Rasul, maka rumah menjadi tempat beribadah dan sekaligus bermisi. Fungsi dan manfaat yang dapat diwujudkan dari praktik gereja rumah adalah kegerakan-kegerakan misi. Dan hal itu dapat diterapkan dalam konteks masa kini, di mana orang Kristen "dipaksa" oleh keadaannya untuk beribadah di rumah. Bahkan hingga paska pandemi Covid-19 pun, yaitu memasuki New Normal sepertinya pola gereja rumah dapat menjadi rujukan yang terus dikembangkan dalam pola misi masa depan. New normal adalah istilah yang digunakan untuk menyiratkan bahwa segala sesuatu yang tidak biasa atau belum pernah dilakukan sebelumnya menjadi kebiasaan baru dalam aktifitas/berperilaku. Badan bahasa Kemendikbud menyepadankan kata new normal dengan kata kenormalan baru, yaitu keadaan normal yang baru (belum pernah ada sebelumnya). Bahkan

${ }^{24}$ Fransiskus Irwan Widjaja and Candra Gunawan Marisi, "Menstimulasi Praktik Gereja Rumah Di Tengah Pandemi Covid-19" 2019, no. Sinta 2 (2020): 127-139.

${ }^{25}$ Djeffry Hidajat, "Gereja Di Rumah: Kontekstualisasi Fungsi-Fungsi Rumah Dalam Masa Perjanjian Baru Untuk Pekabaran Injil," Veritas : Jurnal Teologi dan Pelayanan 17, no. 2 (December 1, 2018): 107-117, https://ojs.seabs.ac.id/index.php/Veritas/article/view/310. 
Pemerintah Indonesia menyebutkan istilah kenormalan baru (new normal) adalah tatanan baru untuk beradaptasi dengan Covid-19 sehingga terjadi produktivitas nasional. Dalam konteks ibadah (gereja), kenormalan baru (new normal) dilakukan dengan penerapan protokol kesehatan pencegahan dan penanggulangan Covid-19 ini. Hal ini sangat tidak memungkinkan untuk menggelar ibadah dalam jumlah kerumunan besar, sehingga menjadikan banyak jemaat (keluarga) tidak terlayani dengan maksimal. Oleh karenanya, konsep gereja rumah menjadi rujukan yang dapat diimplementasikan segera dalam menyambut tatanan baru atau kenormalan baru (new normal).

Kembali pada esensi ibadah yang ingin dibangun, yakni pertumbuhan iman dalam pengenalan pribadi kepada Yesus Kristus, sehingga menghasilkan buah iman, baik dalam bentuk kedewasaan dan jiwa yang dimenangkan. Jadi, implikasi berikut yang tidak dapat dilepaskan dari ibadah rumah tangga ini adalah melakukan misi Amanat Agung Yesus Kristus. Ibadah Minggu di dalam rumah menjadi satu tawaran dan sekaligus strategi yang dibangun oleh gereja itu sendiri untuk, pertama-tama, memperkuat sendi kehidupan iman keluarga Kristen, lalu dapat menjangkau orang-orang yang dapat dihadirkan di "rumah" orang percaya. ${ }^{26}$ Dengan demikian keluarga menjadi pusat misi masa kini.

\section{KESIMPULAN}

Pola Alkitab selalu menempatkan keluarga sebagai pusat misi, baik mulai pada masa PL maupun masa PB. Gereja mula-mula dan pergerakan misi Amanat Agung dapat dilihat dari apa yang dilakukan oleh rasul Paulus dalam Kisah Para Rasul dan surat-surat penggembalaannya. Banyak rujukan yang dapat memberi kesimpulan bahwa pola misi penginjilan Paulus adalah berpusat pada keluarga. Dewasa ini sepertinya pola ini mulai memudar. Misi dipandang sebagai sesuatu yang hanya dapat dikerjakan oleh orang-orang tertentu (misionaris). Hal ini telah menjadikan misi sebagai sesuatu yang asing di mata bahkan hati orang percaya. Keluarga hanya sebagai komunitas yang menjadi obyek pelayanan gerejawi bukan menjadi subyek pelaku misi amanat agung. Hingga pada masa pandemi Covid-19 terjadi, memaksa semua kegiatan berpusat dari rumah. Bekerja, belajar dan beribadah dari rumah membawa suatu perubahan pada tatanan kehidupan manusia. Hal ini membawa perspektif misi masa kini harus mengalami perubahan. Kembali pada pola Alkitab yaitu menjadikan keluarga sebagai pusat misi. Adapun yang menjadi kesimpulan pada penelitian ini adalah: Pertama, keluarga memiliki suatu hubungan yang erat dengan misi Amanat Agung. Penjelasan dalam Alkitab menjadikan pola misi selalu berpusat pada keluarga. Kedua, pemahaman misi telah

${ }^{26}$ Widjaja and Marisi, "Menstimulasi Praktik Gereja Rumah Di Tengah Pandemi Covid-19." 
bergeser, di mana bukan lagi keluarga sebagai pusat misi. Misi menjadi sesuatu yang asing bagi keluarga kristen, hanya dapat dilakukan oleh orang-orang tertentu (misionaris). Ketiga, pandemi Covid-19 telah memaksa untuk mengkaji dan mendefinisikan ulang tentang pemahaman misi amanat agung. Misi model Alkitab menjadi pola terbaik sebagai rujukan perspektif misi masa kini, yaitu kembali menjadikan keluarga sebagai pusat misi. Ke-empat, menyambut kenormalan baru (new normal), di mana terjadi pembatasan-pembatasan beribadah dengan protokol kesehatan penanggulangan dan pencegahan Covid-19 yang tidak memungkinkan untuk menghadirkan banyak orang melakukan ibadah. Pola gereja rumah seperti pola gereja mula-mula menjadi usulan dan rujukan yang paling tepat dalam masa kenormalan baru (new normal). Gereja harus berkonsentrasi terhadap keluarga. Ibadah Minggu di dalam rumah menjadi satu tawaran dan sekaligus strategi yang dibangun oleh gereja itu sendiri untuk; pertama-tama memperkuat sendi kehidupan iman keluarga Kristen, lalu dapat menjangkau orang-orang yang dapat dihadirkan di "rumah" orang percaya dan membentuk anggota keluarga menjadi pribadi yang berani menyaksikan imannya.

\section{KEPUSTAKAAN}

Dan, Tantangai, Kesempatan Dalam, Tugas Pbi, Ggembalaan Gerbja, D I Era, P O S Modernisme, and I Hal. "Ke-L8, Dan" (n.d.).

Dwiraharjo, Susanto. "Kajian Eksegetikal Amanat Agung Menurut Matius 28 : 1820." Jurnal Teologi Gracia Deo 1, no. 2 (2019): 56-73.

Hartono, Handreas. "Mengaktualisasikan Amanat Agung Matius 28 : 19-20 Dalam Konteks Era Digital." KURIOS (Jurnal Teologi dan Pendidikan Agama Kristen) 4, no. 2 (2018): 157-166.

Hidajat, Djeffry. "Gereja Di Rumah: Kontekstualisasi Fungsi-Fungsi Rumah Dalam Masa Perjanjian Baru Untuk Pekabaran Injil.” Veritas : Jurnal Teologi dan Pelayanan 17, no. 2 (December 1, 2018): 107-117. https://ojs.seabs.ac.id/index.php/Veritas/article/view/310.

Simanjuntak, Fredy. "Problematika Disorganisasi Dan Disharmonisasi Keluarga." In Keluarga Yang Misioner, 81-91, 2018.

Susanta, Yohanes Krismantyo. "Tradisi Pendidikan Iman Anak Dalam Perjanjian Lama." BIA': Jurnal Teologi dan Pendidikan Kristen Kontekstual 2, no. 2 (2019): 139-150.

Verkuyl, Johannes, Johannes Verkuyl, Misi Menurut, and Perspektif Alkitab. "Johannes Verkuyl Dalam John R. W. Stott, Johannes Verkuyl, Dkk., Misi Menurut Perspektif Alkitab, Dasar Dan Prinsip Penginjilan Sedunia (Jakarta: Yayasan Komunikasi Bina Bangsa, 2007), Hal 73 - 75” (2007): 2007. 
Widjaja, Fransiskus Irwan. Misiologi Antara Teori, Fakta Dan Pengalaman. 1st ed. Batam: Andi Offset Yogyakarta, 2018.

Widjaja, Fransiskus Irwan, Daniel Ginting, and Sabar Manahan Hutagalung.

"Teologi Misi Sebagai Teologi Amanat Agung" 1, no. 1 (2019): 17-24.

Widjaja, Fransiskus Irwan, and Candra Gunawan Marisi. "Menstimulasi Praktik

Gereja Rumah Di Tengah Pandemi Covid-19” 2019, no. Sinta 2 (2020): 127139.

Widjaja, Fransiskus Irwan, Fredy Simanjuntak, and Noh Ibrahim Boiliu.

"Repositioning Mission in Postmodern Culture." In Proceedings of the 1st International Conference on Education, Society, Economy, Humanity and Environment (ICESHE 2019). Paris, France: Atlantis Press, 2020.

https://www.atlantis-press.com/article/125936174.

Zaluchu, Sonny Eli. "Strategi Penelitian Kualitatif Dan Kuantitatif Di Dalam

Penelitian Agama." Evangelikal 4, no. 1 (2020): 28-38.

"Arie De Kuiper.Pdf," n.d.

"Bagus Surjantoro.Pdf," n.d.

"Donald Guthrie, Teologi Perjanjian Baru 1, Allah, Manusia, Kristus, (Jakarta: BPK Gunung Mulia, 1992), Hal 105” (1992): 1992.

"Gery T Meador.Pdf," n.d.

"Jim Petersen Dan Mike Shamy, Menjadi Garam Dan Terang Bagi Kalangan Terdekat, Bandung: Pioner Jaya, 2007 Hal 7" (2007): 2007.

"John Piper, Jadikan Segala Bangsa Bersuka Cita (Bandung: Lembaga Literatur Baptis, 1993), Hal 7 - 8" (1993): 1993.

"Stephen Tong.Pdf," n.d.

"Togardo Siburian, Kerangka Teologi Religionum Misioner, (Bandung: STT

Bandung, 2004), Hal 81" (2004): 2004.

"Yakob Tomatala, Teologi Misi.Pdf," n.d.

"Yakob Tomatala.Pdf," n.d. 